\title{
Responses of an abyssal meiobenthic community to short-term burial with crushed nodule particles in the south-east Pacific
}

\author{
Lisa Mevenkamp ${ }^{1}$, Katja Guilini ${ }^{1}$, Antje Boetius ${ }^{2}$, Johan De Grave ${ }^{3}$, Brecht Laforce $^{4}$, Dimitri Vandenberghe ${ }^{3}$, \\ Laszlo Vincze $^{4}$, and Ann Vanreusel ${ }^{1}$ \\ ${ }^{1}$ Department of Biology, Marine Biology Research Group, Ghent University, Ghent, Belgium \\ ${ }^{2}$ HGF MPG Joint Research Group for Deep-Sea Ecology and Technology, Max Planck Institute for Marine Microbiology, \\ Celsiusstr. 1, Bremen, Germany \\ ${ }^{3}$ Department of Geology, Mineralogy and Petrology Research Unit, Ghent University, Ghent, Belgium \\ ${ }^{4}$ Department of Chemistry, X-ray Imaging and Microspectroscopy Research Group, Ghent University, Ghent, Belgium
}

Correspondence: Lisa Mevenkamp (lisa.mevenkamp@ugent.be)

Received: 24 November 2018 - Discussion started: 7 December 2018

Revised: 3 May 2019 - Accepted: 15 May 2019 - Published: 6 June 2019

\begin{abstract}
Increasing industrial metal demands due to rapid technological developments may drive the prospection and exploitation of deep-sea mineral resources such as polymetallic nodules. To date, the potential environmental consequences of mining operations in the remote deep sea are poorly known. Experimental studies are scarce, especially with regard to the effect of sediment and nodule debris depositions as a consequence of seabed mining. To elucidate the potential effects of the deposition of crushed polymetallic nodule particles on abyssal meiobenthos communities, a short (11d) in situ experiment at the seafloor of the Peru Basin in the south-east Pacific Ocean was conducted in 2015. We covered abyssal, soft sediment with approx. $2 \mathrm{~cm}$ of crushed nodule particles and sampled the sediment after $11 \mathrm{~d}$ of incubation at $4200 \mathrm{~m}$ water depth. Short-term ecological effects on the meiobenthos community were studied including changes in their composition and vertical distribution in the sediment as well as nematode genus composition. Additionally, copper burden in a few similar-sized but randomly selected nematodes was measured by means of micro X-ray fluorescence $(\mu \mathrm{XRF})$. At the end of the experiment, $46 \pm 1 \%$ of the total meiobenthos occurred in the added crushed nodule layer, while abundances decreased in the underlying $2 \mathrm{~cm}$ compared to the same depth interval in undisturbed sediments. Densities and community composition in the deeper $2-5 \mathrm{~cm}$ layers remained similar in covered and uncovered sediments. The migratory response into the added nodule material was particularly seen in polychaetes $(73 \pm 14 \%$, rel-
\end{abstract}

ative abundance across all depth layers) copepods ( $71 \pm 6 \%)$, nauplii $(61 \pm 9 \%)$ and nematodes $(43 \pm 1 \%)$. While the dominant nematode genera in the added nodule material did not differ from those in underlying layers or the undisturbed sediments, feeding type proportions in this layer were altered, with a $9 \%$ decrease of non-selective deposit feeders and an $8 \%$ increase in epistrate feeders. Nematode tissue copper burden did not show elevated copper toxicity resulting from burial with crushed nodule particles. Our results indicate that burial with a $2 \mathrm{~cm}$ layer of crushed nodule particles induces changes in the vertical structure of meiobenthos inside the sediment and an alteration of nematode feeding type proportions within a short time frame of $11 \mathrm{~d}$, while nematode tissue copper burden remains unchanged. These findings considerably contribute to the understanding of the short-term responses of meiobenthos to physical disturbances in the deep sea.

\section{Introduction}

The interest in mineral deposits from the deep seafloor commenced in the early 1970s, after the discovery of a widespread occurrence of economically valuable polymetallic nodules (Mero, 1977; Glasby, 2000). However, economic and technological limitations of using deep-sea resources at that time hampered further industrial activities. The advancements in deep-sea technology and other socio-economic de- 
velopments have led to a new surge in deep-sea minerals in the past decade, and legal frameworks are being developed to manage their exploitation in international waters (Lodge et al., 2014). Polymetallic nodules are decimetre-sized concretions of ore lying on the surface of abyssal sediments in $4000-6500 \mathrm{~m}$ water depth and cover large areas of the Pacific and Indian Ocean (Hein and Koschinsky, 2014). Besides the high content in valuable metals such as copper, nickel and cobalt, polymetallic nodules exhibit a high porosity, low bulk density and fine grain size, with very slow formation and growth rates of 5 to $250 \mathrm{~mm} \mathrm{Myr}^{-1}$ (million years) (Von Stackelberg, 2000; Hein et al., 2013). These properties result in very brittle structures that are easily damaged or broken when applying low force (Thiel et al., 1993; Jain et al., 1999; Charewicz et al., 2001; Zenhorst, 2016). Therefore, breakage and abrasion of nodule particles is likely to occur during a mining operation with heavy gear, for example during separation of nodules and sediment as part of the collection process or by the shear stress of the water jet used for the collection and transport of nodules.

Polymetallic nodule mining is hence expected to have various direct and indirect environmental impacts due to nodule removal, removal of surface sediment, sediment compaction, sediment suspension and deposition, organic matter dilution and redistribution, discharge of waste material and potential release of toxic amounts of heavy metals (Rolinski et al., 2001; Sharma et al., 2001; Thiel, 2001; Clark and Smith, 2013). Additionally, nodule particles abraded during collection may get mixed with the suspended sediment and redeposited in areas close to or further away from the mined site, depending on their sedimentation rate. An economically viable mining operation would cover an area of 300$800 \mathrm{~km}^{2} \mathrm{yr}^{-1}$ (Smith et al., 2008) and after 20 years an estimated $8500 \mathrm{~km}^{2}$ would have been mined per concession area (Madureira et al., 2016). Sedimentation rates in nodule areas are slow and range between 0.2 and $1.15 \mathrm{~cm} \mathrm{kyr}^{-1}$ (Volz et al., 2018), while modelled sedimentation rates for a nodule mining scenario in the North Pacific were more than a thousand times higher than the natural background level (Aleynik et al., 2017). Such a large-scale mining operation is expected to directly impact the nodule-associated fauna (Purser et al., 2016; Vanreusel et al., 2016). However, deposition of sediment and nodule particles on the seafloor resulting from mining activities may also impact the typical abyssal softsediment fauna, but knowledge about the direct responses of those organisms to burial with such material is scarce.

In the abyssal deep sea, the meiobenthos $(32-1000 \mu \mathrm{m})$ constitute the most dominant metazoan component of infaunal communities in terms of biomass (Rex et al., 2006). Due to their high abundance, meiofauna play an important role in the energy flow inside abyssal sediments but also in the functioning of the infaunal ecosystem through, for example, bioturbation, degradation of organic matter or species interactions (Schratzberger and Ingels, 2017). Moreover, meiofauna contribute greatly to the high biodiversity of abyssal ecosystems with nematodes in particular being the most diverse metazoan taxon in some deep-sea habitats (Sinniger et al., 2016). Typically, meiofaunal generation times vary in the range of weeks to months, depending on the species (Gerlach, 1971; Coull, 1999). However, this has only been characterized for shallow water species so far, and generation times may be longer in the deep sea where many taxa are characterized by a high longevity (Cailliet et al., 2001; Giere, 2009).

Due to their residence inside the sediment, nodule mining will inevitably disturb meiobenthic communities, directly or indirectly: directly through the removal of the sediment surface layers, which causes at worst meiofaunal death, but at least removal and redistribution of meiobenthic organisms, and indirectly through sediment deposition, which may have consequences for the survival and vertical structuring of underlying meiobenthic communities.

Previous research on the direct effect of nodule mining suggests that abyssal benthic communities have the capacity to recover from small-scale sediment disturbances (Gollner et al., 2017), although the effects of stress by pollution, oxygen deficiency and forced migration, etc. on overall fitness have not been investigated. In that respect, full recovery of a disturbed community may be a long-lasting process which may still be incomplete several decades after the disturbance (Gollner et al., 2017). Previous findings are based on small-scale disturbance scenarios in which nodules were removed or ploughed (overview given in Jones et al., 2017). In general, recovery of mobile fauna occurred faster than that of sessile fauna, and small organisms tend to recover faster than larger organisms (Gollner et al., 2017; Jones et al., 2017). These deep-sea experiments clearly indicated that sediment disturbance leads to changes in meiofauna community composition and vertical distribution (Kaneko et al., 1997; Miljutin et al., 2011), which has also been observed in experiments on meiobenthic communities from shallower depths (Maurer et al., 1986; Schratzberger et al., 2000; Mevenkamp et al., 2017). However, it remains unclear what thickness of sediment deposition evokes the meiofaunal responses in the deep sea and if it is possible to reproduce the results under more controlled conditions in the short term.

Another possible risk of polymetallic nodule mining is the release of potentially toxic amounts of heavy metals during sediment resuspension and nodule abrasion, with largely unknown effects on deep-sea biota (Hauton et al., 2017). Bioavailability and toxicity of metals inside marine sediments strongly depend on the structure and chemical properties of the sediment, and these complex processes are not yet fully understood (Eggleton and Thomas, 2004). While bulk sediment concentrations of heavy metals such as $\mathrm{Cu}$, $\mathrm{Ni}$ and $\mathrm{Cd}$ are high in a polymetallic nodule area, the concentrations in the porewater, which constitute the potentially bioavailable fraction, are significantly lower, ranging in the sub-parts-per-billion (ppb) or lower ppb level (Koschinsky, 2001; Paul et al., 2018). However, even if porewater concentrations of heavy metals are known, the effective uptake 
of those metals by infaunal organisms may still vary due to physiological adaptations to high metal burdens (Auguste et al., 2016). Therefore, direct measurements of metals in animal tissues may be used to inform about changes in metal uptake induced by polymetallic nodule mining and may indicate physiological responses to increased metal burdens.

To evaluate the short-term effects of nodule particle burial on the structure of the meiobenthos community and metal uptake by nematodes, we deposited a $2 \mathrm{~cm}$ layer of crushed nodule particles on enclosed, undisturbed abyssal sediments in the south-east Pacific at $4200 \mathrm{~m}$ water depth using the remotely operated vehicle (ROV) Kiel 6000. Density and community structure of the meiobenthos as well as their vertical structuring in the sediments after $11 \mathrm{~d}$ of incubation were assessed in treatments with and without crushed nodule particle deposition. Furthermore, nematode genus composition was investigated, and X-ray spectrometric images were taken of nematodes to assess the usefulness of this technique for toxicity assessments in the deep sea.

\section{Material and methods}

\subsection{Experiment set-up and sampling}

The burial experiment was performed in situ during RV Sonne cruise SO242-2 (28 August-1 October 2015) at the southern reference site of the DISCOL experimental area in the Peru Basin, south-east Pacific $\left(7^{\circ} 7.51 \mathrm{~S}, 88^{\circ} 27.02 \mathrm{~W}\right.$; at $4196 \mathrm{~m}$ water depth (Thiel and Schriever, 1989). For this purpose the ROV Kiel 6000 (GEOMAR, Germany) was used to insert six stainless steel rings $(\varnothing=25 \mathrm{~cm}$, height $=15 \mathrm{~cm})$ into undisturbed sediment, avoiding enclosure of nodules or megafauna. The rings were gently pushed $10 \mathrm{~cm}$ into the sediment until the collar around the rings touched the sediment surface (Fig. 1a). Subsequently, a nodule particledistributing device (Fig. S1 in the Supplement) filled with $250 \mathrm{~mL}$ crushed nodule particles was deployed on three of the steel rings (Burial treatment; Fig. 1b). The other three rings enclosed undisturbed sediments, and these served as experimental controls (Control). Rotation of the T-handle activated the release of the nodule material that was filled inside the tubes of the device. This resulted in a roughly homogenous distribution of crushed nodule particles onto the sediment surface in the steel ring, with a thickness of approximately $2 \mathrm{~cm}$ (Fig. 1c). To obtain the crushed nodule particles, several nodules from the experimental site were collected $2 \mathrm{~d}$ prior to the experiment. Upon retrieval, epifauna, if present, were removed from the nodules, and nodules were thoroughly washed with fresh water to remove all sediment and fauna. Subsequently, nodules were put inside plastic bags and manually crushed with a hammer. The resulting nodule particles varied in size between $3 \mu \mathrm{m}$ and $1 \mathrm{~cm}$ (Fig. S2 in the Supplement).
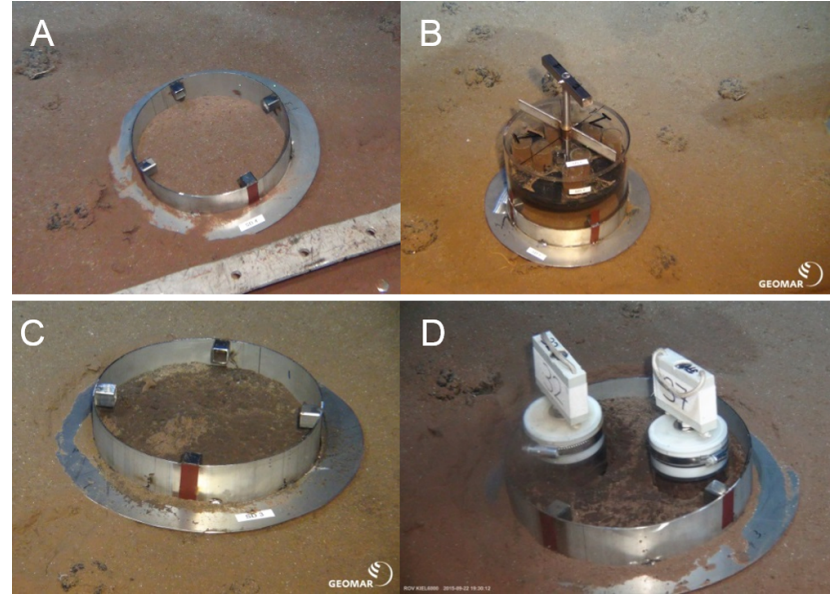

Figure 1. Images of the deployment and sampling during the in situ experiment. (a) Stainless steel ring pressed into the abyssal sediment. (b) Filled nodule particle-distributing device on top of the stainless steel ring before release of the nodule material. (c) Sediment surface after $11 \mathrm{~d}$ of incubation. (d) Push core sampling at the end of the experiment. Copyright: ROV Kiel 6000 Team/GEOMAR, Germany.

After $\sim 20 \mathrm{~h}$, the sediment distributing devices were removed from the steel rings to allow complete settlement of all nodule particles and to ensure open water exposure during the remaining time of the experiment. After a total incubation time of $11 \mathrm{~d}$, the sediment in each steel ring was subsampled with two push cores $(7.4 \mathrm{~cm}$ inner diameter; Fig. 1d).

On board, the overlying water in the push cores was carefully siphoned off and sieved $(32 \mu \mathrm{m})$ to retain any meiobenthos. Subsequently, the sediment of each push core was sliced in several depth layers (added nodule particle layer (NOD), $0-1,1-2$ and $2-5 \mathrm{~cm}$ sediment depth) in a climatecontrolled room at in situ temperature $\left(2.9^{\circ} \mathrm{C}\right)$. The sediment of each slice from all push cores was homogenized, and a $5 \mathrm{~mL}$ subsample was taken for bulk sediment metal content analysis and stored at $-20^{\circ} \mathrm{C}$. Of each set of push cores, one was used for meiobenthos community analysis, and the sediment from each slice was fixed in $4 \%$ boraxbuffered formaldehyde. The retained meiobenthos from the overlying water of that core was added to the sample of the uppermost sediment layer. The second push core was used to analyse sediment characteristics (granulometry, total organic carbon content, total nitrogen content), and sediment from each slice was stored at $-20^{\circ} \mathrm{C}$ until further analysis. Unfortunately, one core of the Control treatment was lost during slicing, leaving two replicates for environmental analyses.

\subsection{Meiobenthos analysis}

Meiobenthos sediment samples were washed on two stacked sieves of $32 \mu \mathrm{m}$ (lower sieve) and $1000 \mu \mathrm{m}$ (upper sieve). Meiofauna were extracted from the $32 \mu \mathrm{m}$ fraction by density 
gradient centrifugation with the colloidal silica solution Ludox HS40 (specific gravity of 1.18) (Somerfield et al., 2005). After each of the three centrifugation rounds $(3000 \mathrm{rpm}$, $12 \mathrm{~min}$ ), the meiobenthos in the supernatant was retained on a $32 \mu \mathrm{m}$ sieve. Subsequently, the sample was fixed in $4 \%$ buffered formaldehyde and stained with a few drops of Rose Bengal solution. The meiobenthos were identified to higher taxonomic level using a stereomicroscope $(50 \times$ magnification).

From each sample, approximately 50 nematodes were picked, transferred stepwise to anhydrous glycerine following the formalin-ethanol-glycerol protocol of De Grisse (1969) and mounted on paraffin-ring glass slides for microscopic identification. Nematodes were identified with a Leica DMLS compound microscope $(10 \times 100 \times$ magnification) to genus level, consulting mainly the original species descriptions and pictorial keys available on the Nemys website (Bezerra et al., 2018). Furthermore, nematode genera were categorized in four feeding guilds based on their buccal cavity morphology as described by Wieser (1953). Feeding guilds included "selective deposit feeders" (Group 1A, small buccal cavity without teeth), "non-selective deposit feeders" (Group 1B, large buccal cavity without teeth), "epistrate feeders" (Group 2A, small buccal cavity with teeth) and "predators/scavengers" (Group 2B, lager buccal cavity with teeth). The mouthless genus Parastomonema was grouped separately ("mouthless").

\subsection{Sediment characteristics and metal contents}

Sediment grain size analysis was carried out by laser diffraction with a Malvern Mastersizer 2000 particle analyser (Malvern Instruments, UK), and sediment fractions were classified according to Wentworth (1922). Total organic carbon (TOC) and total nitrogen (TN) content in the sediments were analysed with an element analyser Flash 2000 (Thermo Fisher Scientific) after lyophilization, homogenization and acidification with $1 \% \mathrm{HCl}$.

Sediment bulk concentrations of $\mathrm{Fe}_{2} \mathrm{O}_{3}(\%), \mathrm{MnO}(\%)$, $\mathrm{Cu}, \mathrm{Ni}$ and $\mathrm{Co}(\mathrm{ppm})$ were determined by inductively coupled plasma optical emission spectrometry (ICP-OES) following protocol no. 14869-2:2002(E) of the International Organization for Standardization (2002). Porewater metal content was not measured in this study but has been assessed for the experimental area by Paul et al. (2018)

\subsection{Individual nematode copper content}

To determine copper contents in nematodes, respectively 6 and 11 similar-sized and shaped nematodes were taken from one sample of the added crushed nodule layer and the uppermost layer of a push core sample taken from the same experimental area during the incubation period and processed as described above. Nematodes were transferred to a drop of water, and body length $(L, \mu \mathrm{m}$, excluding filiform tail) and average width $(W, \mu \mathrm{m}$, measured at three different positions in the middle body region) were determined under a compound microscope connected to a Leica camera system. These measures were used to estimate nematode wet weight (WW) using an adjusted Andrassy (1956) formula to account for the specific gravity of marine nematodes (i.e. $1.13 \mathrm{~g} \mathrm{~cm}^{-1}$ ): $\mu \mathrm{g} \mathrm{WW}=\mathrm{L} \times \mathrm{W}^{2} / 1500000$ (as described in Pape et al., 2013).

Nematodes were then mounted on $500 \mathrm{~nm}$ thin silicon nitride membranes (Silson Ltd, UK) by means of a small drop of ultrapure water and left to air-dry. Subsequently, element contents were assessed by means of micro X-ray fluorescence ( $\mu \mathrm{XRF}$ ) using the Edax Eagle III (Edax Inc., USA). This instrument is equipped with a $50 \mathrm{~W} \mathrm{Rh} \mathrm{X}$-ray tube fitted with polycapillary optics, which focus the X-ray beam in a $30 \mu \mathrm{m}$ spot. A liquid nitrogen cooled $\mathrm{Si}(\mathrm{Li})$ detector is employed to capture the fluorescent X-rays. To examine the element content of the organisms, small mappings were performed with $30 \mu \mathrm{m}$ step size; each measurement point of these mapping contains a full XRF spectrum with $10 \mathrm{~s}$. These spectra are analysed using AXIL, an iterative least squares algorithm yielding the net intensities for each detectable element present in the sample. The points belonging to the organism are extracted from the XRF element maps using $k$ means clustering. Next, the spectra from these data points are summed to obtain the total intensity generated by the nematode during the measurement. The intensities per nematode are normalized using nematode wet weights. Of the heavy metals, copper $(\mathrm{Cu})$ was the only element visible clearly enough in the XRF spectra to yield reliable results. Due to the small diameter of the organisms $(\sim 30 \mu \mathrm{m})$ the absorption effects on $\mathrm{Cu}$ are negligible, so the normalized intensities of the different scans can be compared directly with each other. In other words, a nematode with more $\mathrm{Cu}$ present in its body will yield a higher intensity (counts) per unit body mass (in micrograms, $\mu \mathrm{g}$ ).

\subsection{Data analysis}

Meiobenthos densities are expressed as the number of individuals per $10 \mathrm{~cm}^{2}$ in the different depth layers and over the whole sampled depth (total densities). Due to the unequal thickness of the sampled depth layers, differences in community composition were examined based on relative abundances of the different meiobenthic taxa in each depth layer.

$K$-dominance curves of nematode genera over the whole core were calculated based on untransformed density data (ind. $10 \mathrm{~cm}^{2}$ ) and plotted in Primer 6 (Clarke and Gorley, 2006). Additionally, diversity indices (Shannon-Wiener index using the natural logarithm $\left(H^{\prime}\right)$, Pielou's evenness $\left(J^{\prime}\right)$ and Simpson's index of diversity $(1-D))$ of the whole core community were compared between treatments in univariate analyses. Differences in nematode genus composition between treatments and depth layers were analysed based on relative abundance only. 
Statistical differences between treatments and depth layers in multivariate datasets (sediment TOC and TN contents, meiobenthos community composition, nematode genus composition, nematode feeding types) were investigated with a cluster analysis (cluster mode is the group average) combined with a similarity profile test (SIMPROF) using Primer 6. For abiotic data, a resemblance matrix based on Euclidean distances was used, while biotic data (meiobenthos and nematode genus composition, nematode feeding types) were analysed based on Bray-Curtis similarities. Visual interpretation of the results was carried out using multidimensional scaling (MDS) plots and a similarity percentages analysis (SIMPER) of significant cluster groups.

Differences of univariate measures (bulk sediment metal contents, total meiobenthos densities and diversity indices) between treatments were tested with a Student's $t$ test in R (R Core Team, 2013) after ensuring normality (Shapiro-Wilk test) and homoscedasticity (Levene's test) of the data or, alternatively, with a non-parametric Wilcoxon test if datasets failed parametric assumptions of normality and homogeneity of variances.

An $\alpha=0.05$ significance level was chosen for all statistical analyses.

\section{Results}

\subsection{Sediment characteristics and metal contents}

The sediment in all push cores was characterized by a 10 $20 \mathrm{~cm}$ thick brown layer of fluffy surface sediment with underlying more compact, whitish subsurface sediment, and no differences in the coloration were apparent between the Control and the Burial treatment at the end of the experiment (Fig. S3 in the Supplement).

The analysis of total organic carbon and nitrogen contents between treatments and depth layers revealed two significant clusters branching at a distance of $0.4(\pi=0.03, p=0.001)$. The first cluster was composed of all added nodule particle layers (NOD), and the second cluster contained all remaining sediment layers of both treatments. Differences were caused by lower TN and TOC contents in the crushed nodule layer (TN: $0.20 \pm 0.00 \%$, TOC: $0.39 \pm 0.00 \%$; mean \pm standard error (SE)) compared to the Control (TN: $0.41 \pm 0.05 \%$, TOC: $0.77 \pm 0.02 \%)$ and the underlying sediment layers (TN: $0.40 \pm 0.02 \%$, TOC: $0.71 \pm 0.02$ ). Despite the lower carbon and nitrogen content in the nodule particles, the $\mathrm{C} / \mathrm{N}$ ratio remained similar between the crushed nodule material $(1.926 \pm 0.037)$ and the Control sediment $(1.951 \pm 0.177)$.

The Control sediment mainly consisted of silt (75.6 \pm $0.2 \%$; mean $\pm \mathrm{SE}$ ), clay $(12.8 \pm 0.2 \%)$ and very fine sand $(8.9 \pm 0.2 \%)$, with a median grain size of $20.8 \pm 0.3 \mu \mathrm{m}$, which was similar in the $0-5 \mathrm{~cm}$ of the Burial treatment sediment (median grain size: $22.0 \pm 0.3 \mu \mathrm{m}$ ). In contrast, the
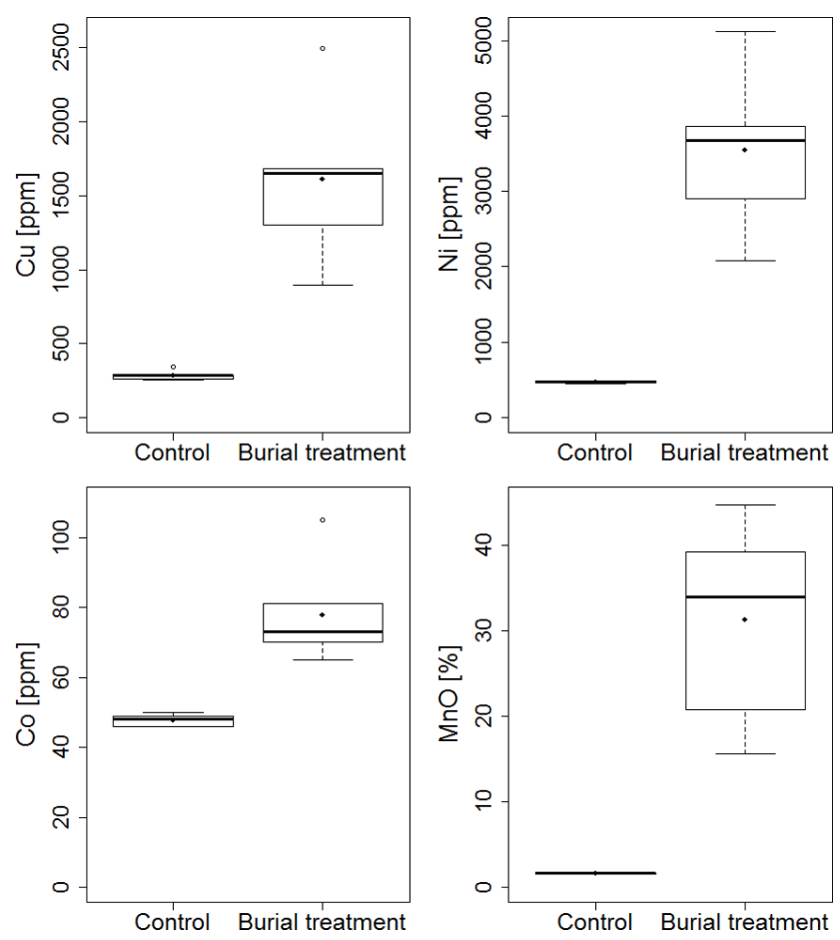

Figure 2. Box and whisker plot of solid-phase metal contents measured in the $0-1 \mathrm{~cm}$ layer of the Control and the added crushed nodule layer of the Burial treatment. Black lines depict the median, whereas dots indicate the mean of the measurements.

crushed nodule material contained much coarser grain fragments in the millimetre to centimetre range (Fig. S2).

Concentrations of $\mathrm{Cu}, \mathrm{Mn}$ and $\mathrm{Ni}$ in the solid phase were more than 3 times higher in the crushed nodule material compared to the Control sediments (Fig. 2).

\subsection{Meiobenthic community composition and vertical distribution}

After $11 \mathrm{~d}$ of incubation, total meiobenthos densities ranged from $275 \pm 10$ ind. $10 \mathrm{~cm}^{-2}$ (mean $\pm \mathrm{SE}$ ) in the Burial treatment to $303 \pm 24$ ind. $10 \mathrm{~cm}^{-2}$ in the Control and did not differ between both treatments (Fig. 3a). Overall, nematodes dominated the meiobenthos community $(91.0 \pm 1.1 \%$, mean $\pm \mathrm{SE})$, followed by harpacticoid copepods $(4.4 \pm$ $0.6 \%)$, nauplii $(3.2 \pm 0.7 \%)$ and polychaetes $(0.6 \pm 0.1 \%$; Fig. 3b). All other taxa (Ostracoda, Tardigrada, Gastrotricha, Isopoda, Mollusca, Tantulocarida and Loricifera) contributed less than $0.5 \%$ to the meiobenthos community.

In the Control, meiobenthos densities were similar across all depth layers, with $40 \pm 3 \%$ of the meiobenthos occurring in the $0-1 \mathrm{~cm}$ layer, $28 \pm 5 \%$ in the $1-2 \mathrm{~cm}$ layer and $32 \pm 4 \%$ in the $2-5 \mathrm{~cm}$ layer (Fig. 3a). This vertical distribution was different in the Burial treatment, where $46 \pm 1 \%$ of meiobenthos occurred in the added crushed nodule layer, $13 \pm 1 \%$ in the $0-1 \mathrm{~cm}$ layer, $10 \pm 1 \%$ in the $1-2 \mathrm{~cm}$ layer and $32 \pm 2 \%$ in the $2-5 \mathrm{~cm}$ layer (Fig. 3a). While at the end of the experi- 
(a)

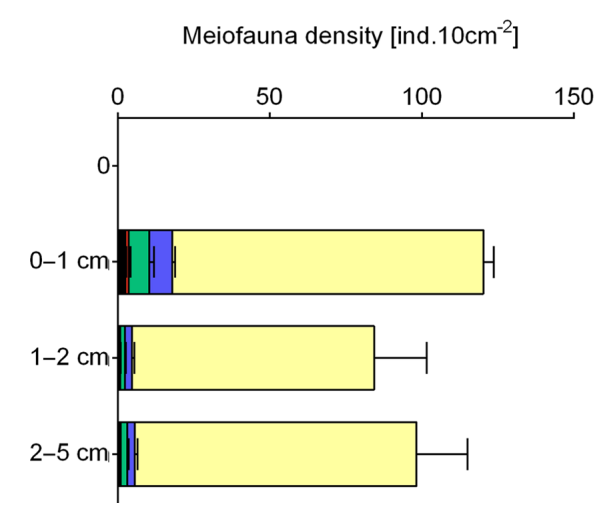

(b) Burial treatment

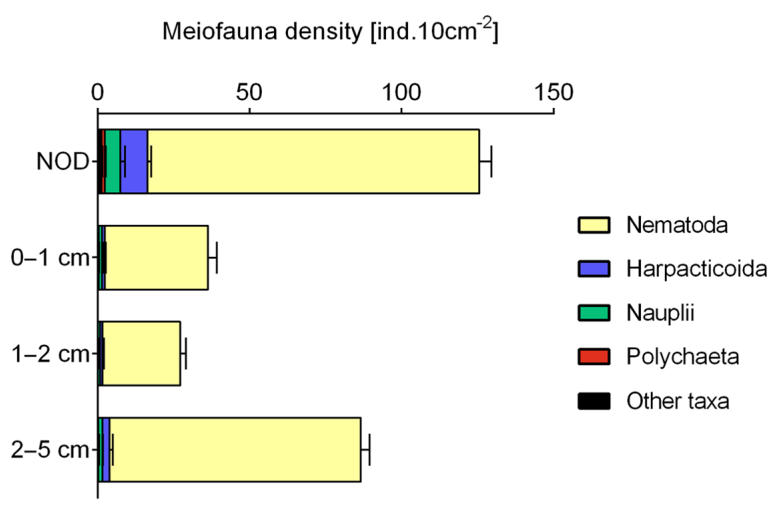

Figure 3. Vertical profile of the average meiobenthos densities (ind. $10 \mathrm{~cm}^{-2}+$ standard error) in the Control and Burial treatment with a $\pm 2 \mathrm{~cm}$ layer of crushed nodule particles (NOD).

ment $43 \pm 1 \%$ of nematodes over all depth layers were found in the added crushed nodule layer, this percentage was much higher for polychaetes $(73 \pm 14 \%)$, copepods $(71 \pm 6 \%)$ and nauplii $(61 \pm 9 \%)$.

Whole core meiobenthos community composition was similar in samples of both treatments. However, when taking depth layers into account, two significant clusters were revealed branching at a similarity level of $92 \%(\pi=0.99$, $p=0.001$ ). The first cluster (Cluster A) was composed of all crushed nodule layers (NOD), all 0-1 cm layers of the Control and one sample of the 1-2 cm layer of the Burial treatment (Fig. 4), while the second cluster (Cluster B) was composed of all remaining samples. Similarities between both clusters were caused by lower abundances of nematodes and higher abundances of copepods, nauplii and polychaetes in Cluster A compared to Cluster B (SIMPER contributions: $48 \%, 25 \%, 15 \%$ and $4 \%$, respectively; Table 1 ).

\subsection{Nematode genus community composition}

The nematode genus community was very diverse and composed of 96 genera from 33 families combining all samples (Table S1 in the Supplement). Of the total number of genera, 26 were only recorded once (singletons), and 18 were recorded twice (doubletons). The dominant genera included

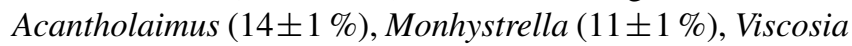
$(8 \pm 3 \%)$ and Thalassomonhystera $(5 \pm 1 \%)$. Of the other genera, each contributed less than $5 \%$ to the overall nematode community. Evenness of nematode genera was higher in the Burial treatment $(0.86 \pm 0.01)$ compared to the Control $\left(0.81 \pm 0.01 ; t_{2.73}=-3.373, p=0.0499\right.$, borderline significant; Fig. 5). Diversity indices were not significantly different between the Burial treatment (Shannon: $3.23 \pm 0.06$, Simpson: 0.95 \pm 0.01 ) and the Control (Shannon: $3.16 \pm 0.08$, Simpson: $0.93 \pm 0.01$; Fig. 5).

The cluster analysis of relative abundances of nematode genus composition revealed two significant clusters branch-
2-D stress: 0.03
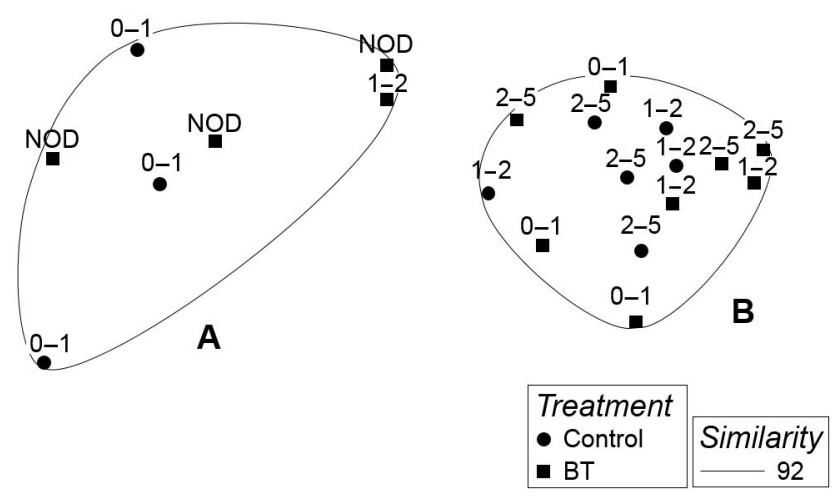

Figure 4. MDS plot of the meiobenthos community in each sample of the Control and Burial treatment (BT) per sediment depth layer with overlying contours of significant (SIMPROF test) clusters at a $92 \%$ similarity level indicated by the letters A and B. NOD is the crushed nodule particle layer.

ing at a similarity level of $36 \%(\pi=1.64, p=0.002$; Fig. S4 in the Supplement). However, due to the low similarity among all samples (likely resulting from the large number of rare genera) and the lack of clear groupings (e.g. samples of similar depth layers or treatments) within the clusters, we could not further interpret this result.

When grouping genera into feeding types and thereby reducing variability between samples, the cluster analysis of relative abundances of nematode feeding types resulted in four significantly different clusters. Cluster A included all crushed nodule layers (NOD) and was different from Cluster B which included most other depth layers from both treatments branching at a similarity of $75 \%(\pi=1.45, p=$ 0.004; Fig. 6). The two other clusters together included four 
Table 1. Results of the SIMPER analysis between the significantly different clusters identified in the dataset of relative meiobenthos abundances in different depth layers. Av.Abund is the average abundance, Av.Diss the average dissimilarity, Diss/SD the average contribution divided by the standard deviation, Contrib\% the contribution to the dissimilarities and Cum.\% the cumulative contribution to the dissimilarities.

\begin{tabular}{lrrrrrr}
\hline Group & $\begin{array}{r}\text { Cluster A } \\
\text { Av.Abund }\end{array}$ & $\begin{array}{r}\text { Cluster B } \\
\text { Av.Abund }\end{array}$ & Av.Diss & Diss/SD & Contrib\% & Cum.\% \\
\hline Nematoda & 87 & 95 & 4 & 3 & 48 & 48 \\
Harpacticoida & 7 & 2 & 2 & 3 & 25 & 73 \\
Nauplii & 4 & 2 & 1 & 1 & 15 & 88 \\
Polychaeta & 1 & 0 & 0 & 1 & 4 & 92 \\
\hline
\end{tabular}

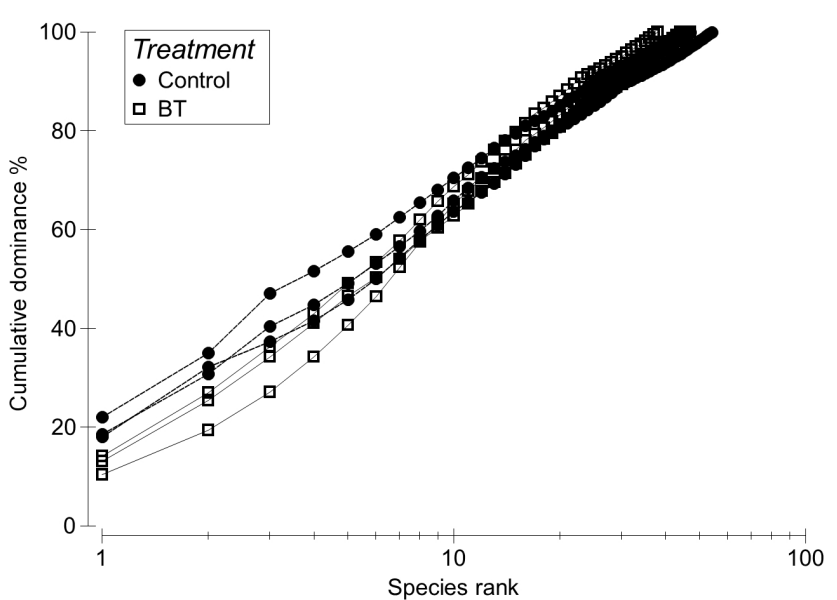

Figure 5. $K$-dominance plot of whole core nematode genera in the Burial treatment (BT) and the Control.

depth layers of both treatments branching at $72 \%$ and $46 \%$ similarity (Cluster C and D, respectively; Fig. 6).

SIMPER analysis indicated that the difference between the main clusters, Cluster A and B, was due to a reduction of non-selective deposit feeders by $9 \%$, an increase in epistrate feeders by $8 \%$, a reduction of selective deposit feeders by $4 \%$ and an increase in predators by $4 \%$, seen in Cluster A compared to Cluster B (SIMPER contributions: $37 \%$, $31 \%$, $16 \%$ and $16 \%$, respectively; Fig. 7).

\subsection{Copper burden in individual nematodes}

Copper contents in nematode bodies could be successfully assessed using micro X-ray fluorescence (Fig. 8a). However, copper burden in the measured nematodes did not differ between treatments (Fig. 8b).

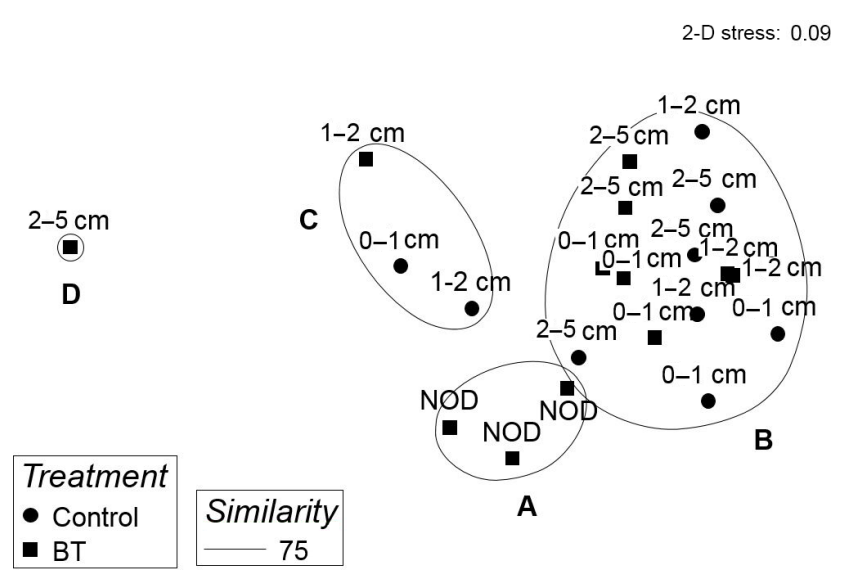

Figure 6. MDS plot of the relative abundances of nematode feeding types in each sample of the Control and Burial treatment (BT) per sediment depth layer with overlying contours of significant (SIMPROF test) clusters at a $75 \%$ similarity level indicated by the letters A-D. NOD is the crushed nodule layer.

\section{Discussion}

\subsection{Crushed nodule particle burial induces changes in meiobenthos community structure}

In a relatively short time span of $11 \mathrm{~d}$, the meiobenthic community in our study responded to burial with crushed nodule particles by migration, adjusting their vertical position in the sediment. Almost half of the meiobenthos $(46 \pm 1 \%)$, represented by all major taxa, had migrated into the added nodule particle layer at the end of the experiment. This migration was predominantly seen by fauna from the upper surface layers $(0-2 \mathrm{~cm})$ which showed strongly reduced densities compared to the same depth layers of the Control. We hypothesize that these organisms from the upper sediment layers are trying to re-establish their position in the sediment by moving upwards, while the mechanism that triggers this response remains unclear. Changes in oxygen penetration could be one such factor.

Migratory responses of meiobenthos have been widely observed and made use of in the past to deliberately extract 

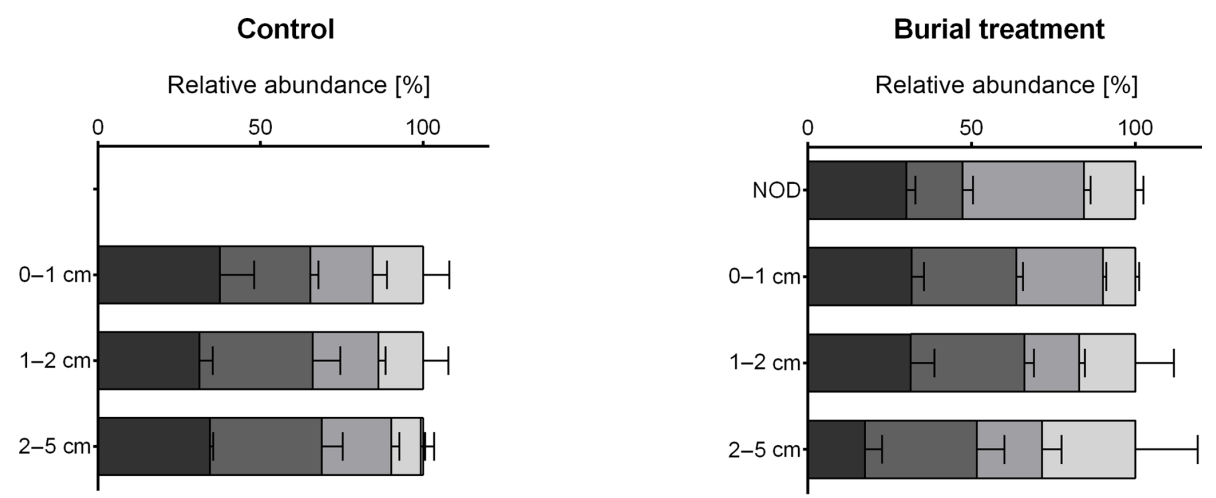

$$
\begin{aligned}
& \square \text { Selective deposit feeders (1A) } \square \text { Non-selective deposit feeders (1B) } \\
& \square \text { Epistrate feeders (2A) } \square \text { Predators / scavengers (2B) } \square \text { Mouthless }
\end{aligned}
$$

Figure 7. Vertical profile of the relative abundance of nematode feeding types per sediment depth layer (percentage + standard error) in the Control and Burial treatment with $\mathrm{a} \pm 2 \mathrm{~cm}$ layer of crushed nodule particles (NOD).

(a)

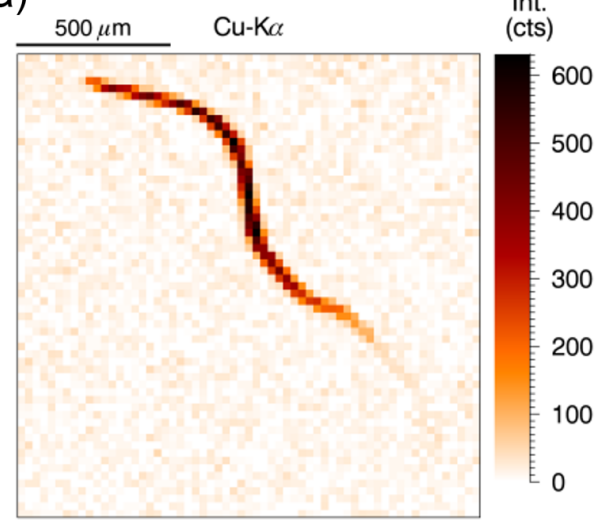

(b)

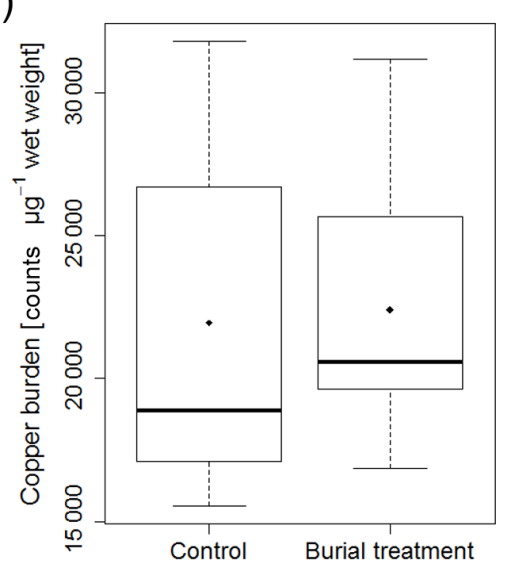

Figure 8. (a) Example image of the copper spectrum from a nematode X-ray mapping indicating copper intensity (counts), which is directly correlated to copper concentration. (b) Box and whisker plot of the copper burden in nematodes from surface sediment layers of a background sample $(n=11)$ and from the crushed nodule material of the Burial treatment $(n=6)$. Black lines depict the median, whereas dots indicate the mean of the measurements.

these organisms from sediments, for example by changing temperature or by using natural gradients of oxygen availability to trigger meiobenthos movement (Uhlig et al., 1973; Rzeznik-Orignac et al., 2004). Moreover, in a short-term laboratory experiment, Mevenkamp et al. (2017) observed significantly reduced oxygen concentrations in the underlying soft sediment after the addition of 0.5 and $3 \mathrm{~cm}$ sediment and an upward migration and increased mortality of nematodes. Unfortunately, we were not able to monitor oxygen content over the time course of the experiment, but the burial with crushed nodule particles could have led to reduced oxygen availability in the surface layer, causing the fauna to migrate upwards. In contrast to the surface fauna, meiobenthos densities in the deeper parts $(2-5 \mathrm{~cm})$ of the sediment remained similar between the Control and the Burial treat- ments, suggesting that the subsurface fauna are less sensitive to the changes in abiotic conditions causing the migratory response.

Changes in vertical nematode distributions have also been reported in a shallow-water study investigating the impacts of the disposal of experimental dredging material (Schratzberger et al., 2000) and a short-term laboratory experiment testing the effect of instantaneous burial with inert tailings and dead, native sediment (Mevenkamp et al., 2017). These studies found that the amount and frequency of sediment burial are interactive factors, showing that frequent but low amounts cause less severe changes than high amounts and instantaneous burial (Schratzberger et al., 2000) but also that burial may cause nematode mortality of up to $50 \%$ in the added material layer, which was measured using 
a staining technique (Mevenkamp et al., 2017). Moreover, Mevenkamp et al. (2017) indicated that burial with $0.1 \mathrm{~cm}$ of tailings may already reduce the functioning of bathyal, benthic fjord communities in terms of fresh organic carbon remineralization. Especially nematode uptake of added organic carbon was considerably reduced after burial with $0.5 \mathrm{~cm}$ of sediment and tailings (Mevenkamp et al., 2017). In contrast, Leduc and Pilditch (2013) reported changes in vertical nematode distribution after experimental resuspension of the upper $5 \mathrm{~cm}$ of sediment originating from bathyal depths $(345 \mathrm{~m})$ but without marked effects on sediment characteristics or community oxygen consumption after 2 and $9 \mathrm{~d}$ following the disturbance. This different response may be attributed to the fact that the same suspended sediment resettled in the experimental units, whereas Mevenkamp et al. (2017) investigated the deposition of natural and non-natural material added on top of the natural sediment.

The possibility that the migratory response may be accompanied by elevated mortality of abyssal meiofauna requires further investigation, especially because re-sedimentation of fine clay is expected to occur over large areas in deepsea mining scenarios (Oebius et al., 2001; Smith et al., 2008). Clay deposition could substantially change oxygen availability in comparison with the coarse nodule debris assessed here. In our experiment, we were not able to assess meiobenthic mortality resulting from the burial because decompression-induced mortality during sample retrieval from abyssal depths would bias the results. Nevertheless, several authors have underlined the importance of assessing meiobenthic mortality in short-term experimental studies as it may pass unnoticed due to slow decomposition of organic matter in the deep sea (Barry et al., 2004; Fleeger et al., 2006, 2010). Therefore, potential unnoticed mortality in our study may have masked more severe changes in terms of meiofauna densities and diversity in our treatments. It should be noted that meiobenthic contribution to the benthic ecosystem in terms of relative abundance and biomass increases with water depth (Rex et al., 2006). Therefore, it is plausible that the induced changes in meiobenthos distribution - and, possibly, mortality - may entail even stronger effects on the overall functioning of abyssal soft sediments with regard to food web interactions, organic matter remineralization and bioturbation.

\subsection{Nematode community may face alterations in response to burial with crushed nodule particles}

Generally, the abyssal seafloor is characterized by a low degree of disturbance and low organic matter input from the euphotic zone. Sedimentation rates in the Peru Basin generally range between 0.4 and $2.0 \mathrm{~cm} \mathrm{ka}^{-1}$ (Haeckel et al., 2001). Therefore, in this environment we expect benthic assemblages to be adapted to very stable conditions. Interestingly, all dominant nematode genera responded with upward migration, and there was no evidence of specific selection mechanisms, e.g. opportunistic genera taking advantage of the new situation and being more successful in either inhabiting the new nodule material or in remaining in the surface layers of the original sediment and, therefore, being more stress-resistant. Opportunistic species generally occur under extreme, variable conditions and get outcompeted by less opportunistic species when disturbance is low (Grassle and Sanders, 1973). However, small-scale disturbances and habitat heterogeneity in the deep sea may induce a more dynamic environment to allow the persistence of colonizing species (Gallucci et al., 2005). This seems to be supported by the large number of Monhysteridae in our study, which are generally classified as good colonizers, at least in shallow water environments (Bongers et al., 1991). However, deep-sea monhysterids are characterized by a high local intra-generic diversity not supporting an opportunistic behaviour (Vanreusel et al., 1997). The results of our experiment did not indicate that monhysterids were more successful in inhabiting the added nodule material.

Nematode communities in the abyssal deep sea and nodule habitats in particular are characterized by a high diversity, potentially owing to the increased habitat complexity created by the nodules (Vanreusel et al., 2010; Miljutin et al., 2011; Singh et al., 2014). Similarly, the nematode community in our experiment displayed a high diversity, with a large proportion of rare genera ( $45 \%$ of the genera recorded only once or twice). This high proportion of rare taxa may increase the vulnerability of the nematode community in this area to disturbances since the risks of local extinction may be greater for those small populations (McCann, 2000; Rosli et al., 2018), and recovery will depend on recolonization success and species connectivity. Information about these two factors is still very limited for nematodes from abyssal nodule regions, especially for the rare taxa. Our study indicated that the addition of crushed nodule particles changed the relative abundance of feeding types in the new surface layer, which could, depending on the long-term effects (e.g. mortality, vertical restructuring, species interactions), affect the role of the nematode community in the functioning of the benthic environment.

A study by Miljutin et al. (2011) indicated that changes in nematode communities following a strong but small-scale sediment disturbance may persist for up to 26 years. They revisited a disturbed nodule site in the equatorial north-east Pacific where sediment and nodules were removed by dredging 26 years ago and found that nematode density, diversity and community structure inside the disturbed track still differed from adjacent non-disturbed areas. Although the disturbance studied by Miljutin et al. (2011) strongly differs from our experiment, it indicates that changes in nematode community composition in polymetallic nodules areas may be long-lasting and are potentially irreversible and, therefore, underline the importance of long-term experiments. 


\subsection{Increased copper concentrations in the added nodule particles are not reflected in nematode body copper content}

The very high concentrations of solid-phase heavy metals in the crushed nodule particles raise questions about bioavailability and uptake of these metals in benthic organisms. Previous research in polluted, shallow waters has shown that nematodes play an important role in the transfer of heavy metals to and from the benthic food web in harbour communities (Fichet et al., 1999) and that uptake of different pollutants may vary (Howell, 1982). As such, Howell (1982) reported increased zinc uptake in nematodes exposed to pollution, while copper content was very variable, and correlations with habitat pollution were less clear.

In the presence of manganese (Mn) oxyhydroxides, other elements such as the transition metals $(\mathrm{Cu}, \mathrm{Ni}, \mathrm{Zn})$ are adsorbed in the oxic layer which is up to $5 \mathrm{~cm}$ deep and locally up to $20 \mathrm{~cm}$ deep in the Peru Basin (Stummeyer and Marchig, 2001). Therefore, most metals are bound to the solid phase of the sediment and are not bioavailable, which may explain our findings of similar copper burdens in the nematodes from the control and the Burial treatments. A recent study investigated the long-term and short-term effects of sediment disturbance on metal and trace element concentrations in the solid phase of the sediment and the porewater (Paul et al., 2018). The authors found that while some solid-phase elements still deviated from pre-disturbance levels even after 26 years, levels of trace metals in the porewater returned to pre-disturbance values in a short time frame of several weeks. Under conditions present in the sampled sediment, release of metals during a mining operation may not result in an increased metal toxicity because of the fast oxidation of $\mathrm{Mn}$ and absorption of metals (Paul et al., 2018). However, in the case that oxygen conditions change inside the sediment due to re-sedimentation or other processes, the release of toxic compounds into the porewater cannot be excluded. The use of new techniques to analyse tissue metal contents as used in this study may allow the precise detection of changes in heavy metal burden, even in smaller benthic organisms, due to mining-related alterations of the abiotic environment.

\subsection{Conclusion and recommendations}

The brittle character of polymetallic nodules implies that deposited material following mining is likely to be a mixture of natural sediment and nodule particles with much lower nodule particle densities than applied in the present study. Therefore, our results cannot be directly transferred to such a scenario. Nevertheless, in this research, we revealed some important insights in the structuring of meiobenthic communities following short-term burial with a relatively thick layer of crushed nodule particles. Despite the very different abiotic conditions in the crushed nodule material and the natural sediment in terms of grain size and carbon and nitrogen content, an upward migration of meiobenthic organisms was observed. Our results from in situ experiments at $>4000 \mathrm{~m}$ water depth are in line with previous research in different habitats such as bathyal fjords and estuaries (Maurer et al., 1986; Schratzberger et al., 2000; Mevenkamp et al., 2017), showing that meiobenthic organisms generally show upward migration following burial with native and non-native substrate.

Furthermore, the relative distribution of nematode feeding types was altered, indicating that changes in the functional role of the nematode community in the short and long term cannot be excluded. Likely due to the high nematode genus diversity and evenness, changes in nematode genus composition were not detected between treatments.

The effect of vertical meiobenthos migration on other benthic size classes and over longer timescales requires further research, especially in a deep-sea mining context in which sediment re-deposition is expected over large areas and long timescales (Murphy et al., 2016). Furthermore, we would like to emphasize that, although it is technically challenging, standardized methods for mortality assessments of fauna in deep-sea sediment samples are needed to advance our understanding of the short-term environmental impacts on the benthos.

Data availability. The data used in this publication are deposited in the PANGAEA database https://doi.pangaea.de/10.1594/ PANGAEA.896027 (last access: 23 May 2019) (Mevenkamp et al., 2018).

Supplement. The supplement related to this article is available online at: https://doi.org/10.5194/bg-16-2329-2019-supplement.

Author contributions. AV, AB, KG and LM conceived the study. LM conducted the experimental work and collected the samples. Meiobenthos samples were analysed by LM and KG, nematode copper content was measured and analysed by BL and LV and sediment metal contents were provided by DV and JDG. LM performed the statistical data analysis. LM, BL, KG and AV interpreted the results, and LM wrote the paper with the assistance of all authors.

Competing interests. The authors declare that they have no conflict of interest.

Special issue statement. This article is part of the special issue "Assessing environmental impacts of deep-sea mining - revisiting decade-old benthic disturbances in Pacific nodule areas". It is not associated with a conference. 
Acknowledgements. The research leading to these results has received funding from the European Union Seventh Framework Programme (FP7/2007-2013) under the MIDAS project (grant agreement no. 603418) and was carried out with infrastructure funded by EMBRC Belgium (FWO project no. GOH3817N). The SO242-2 research cruise was funded by the German Ministry of Education and Science (BMBF; grant agreement no. 03F0707A-G) as a contribution to the European JPI Oceans Pilot Action "Ecological Aspects of Deep Sea Mining”. Lisa Mevenkamp received additional funding by the Flemish BOF research fund (BOF.DC1.2016.0006) and Katja Guilini by the Flemish fund for Scientific Research (grant no. $1242114 N$ ). The authors want to thank the captain and crew of RV Sonne, the team of ROV Kiel 6000 as well as the scientist team on board. This publication reflects only the views of the authors; the EC is not liable for any use that may be made of the information contained herein. Finally, the authors would like to thank Rahul Sharma and two anonymous referees for their constructive criticism and valuable suggestions that helped improving the paper.

Financial support. This research has been supported by the Seventh Framework Programme (MIDAS project, grant no. 603418), the Research Foundation - Flanders (grant nos. GOH3817N and 1242114N), the Special Research Fund Ghent University (BOF) (grant no. BOF.DC1.2016.0006) and the German Ministry of Education and Science (grant no. 03F0707A-G).

Review statement. This paper was edited by Tina Treude and reviewed by Rahul Sharma and two anonymous referees.

\section{References}

Aleynik, D., Inall, M. E., Dale, A., and Vink, A.: Impact of remotely generated eddies on plume dispersion at abyssal mining sites in the Pacific, Sci. Rep.-UK, 7, 16959, https://doi.org/10.1038/s41598-017-16912-2, 2017.

Andrassy, I.: Die Rauminhalts-und Gewichtsbestimmung der Fadenwürmer (Nematoden), Acta Zool. Hung., 2, 1-5, 1956.

Auguste, M., Mestre, N. C., Rocha, T. L., Cardoso, C., CueffGauchard, V., Le Bloa, S., Cambon-Bonavita, M. A., Shillito, B., Zbinden, M., Ravaux, J., and Bebianno, M. J.: Development of an ecotoxicological protocol for the deep-sea fauna using the hydrothermal vent shrimp Rimicaris exoculata, Aquat. Toxicol., 175, 277-285, https://doi.org/10.1016/j.aquatox.2016.03.024, 2016.

Barry, J. P., Buck, K. R., Lovera, C. F., Kuhnz, L., Whaling, P. J., Peltzer, E. T., Walz, P., and Brewer, P. G.: Effects of direct ocean $\mathrm{CO}_{2}$ injection on deep-sea meiofauna, J. Oceanogr., 60, 759-766, 2004

Bezerra, T. N., Decraemer, W., Eisendle-Flöckner, U., Hodda, M., Holovachov, O., Leduc, D., Miljutin, D., Mokievsky, V., Peña Santiago, R., Sharma, J., Smol, N., Tchesunov, A., Venekey, V., Zeng, Z., and Vanreusel, A.: NeMys: World Database of Nematodes, available at: http://nemys.ugent.be/, last access: 2 October 2018.

Bongers, T., Alkemade, R., and Yeates, G. W.: Interpretation of disturbance-induced maturity decrease in marine nematode as- semblages by means of the Maturity Index, Mar. Ecol. Prog. Ser., 76, 135-142, 1991.

Cailliet, G. M., Andrews, A. H., Burton, E. J., Watters, D. L., Kline, D. E., and Ferry-Graham, L. A.: Age determination and validation studies of marine fishes: do deep-dwellers live longer?, Exp. Gerontol., 36, 739-764, https://doi.org/10.1016/S05315565(00)00239-4, 2001.

Charewicz, W. A., Chaoyin, Z., and Chmielewski, T.: The leaching behaviour of ocean polymetallic nodules in chloride solutions, in: Physicochemical Problems of Mineral Processing, edited by: Sadowski, Z., Wroclaw University of Technology, Wroclaw, Poland, 35, 55-66, 2001.

Clark, M. and Smith, S.: Environmental management considerations, in: deep sea minerals: Manganese nodules, A physical, biological, environmental and technical review, edited by: Baker, E. and Beaudoin, Y., SPC., 27-41, 2013.

Clarke, K. R. and Gorley, R. N.: User manual/tutorial, PRIMER-E Ltd., Plymouth, UK, 2006.

Coull, B. C.: Role of meiofauna in estuarine soft-bottom habitats, Australian, J. Ecol., 24, 327-343, https://doi.org/10.1046/j.14429993.1999.00979.x, 1999.

De Grisse, A.: Redescription ou modifications de quelques technique utilisés dans l'etude des nématodes phytoparasitaires, Meded. Rijksfak. LandbWet. Gent, 34, 251-369, 1969.

Eggleton, J. and Thomas, K. V.: A review of factors affecting the release and bioavailability of contaminants during sediment disturbance events, Environ. Int., 30, 973-980, https://doi.org/10.1016/j.envint.2004.03.001, 2004.

Fichet, D., Boucher, G., Radenac, G., and Miramand, P.: Concentration and mobilisation of $\mathrm{Cd}, \mathrm{Cu}, \mathrm{Pb}$ and $\mathrm{Zn}$ by meiofauna populations living in harbour sediment: their role in the heavy metal flux from sediment to food web, Sci. Total Environ.t, 243-244, 263272, https://doi.org/10.1016/S0048-9697(99)00401-5, 1999.

Fleeger, J. W., Carman, K. R., Weisenhorn, P. B., Sofranko, H., Marshall, T., Thistle, D., and Barry, J. P.: Simulated sequestration of anthropogenic carbon dioxide at a deep-sea site: Effects on nematode abundance and biovolume, Deep-Sea Res. Pt. I, 53, 1135-1147, https://doi.org/10.1016/j.dsr.2006.05.007, 2006.

Fleeger, J. W., Johnson, D. S., Carman, K. R., Weisenhorn, P. B., Gabriele, A., Thistle, D., and Barry, J. P.: The response of nematodes to deep-sea $\mathrm{CO}_{2}$ sequestration: A quantile regression approach, Deep-Sea Res. Pt. I, 57, 696-707, https://doi.org/10.1016/j.dsr.2010.03.003, 2010.

Gallucci, F., Steyaert, M., and Moens, T.: Can field distributions of marine predacious nematodes be explained by sediment constraints on their foraging success?, Mar. Ecol. Prog. Ser., 304, 167-178, 2005.

Gerlach, S. A.: On the importance of marine meiofauna for benthos communities, Oecologia, 6, 176-190, 1971.

Giere, O.: Meiobenthology: the microscopic motile fauna of aquatic sediments, Springer, Berlin, Germany, 2009.

Glasby, G. P.: Lessons learned from deep-sea mining, Science, 289, 551-553, https://doi.org/10.1126/science.289.5479.551, 2000.

Gollner, S., Kaiser, S., Menzel, L., Jones, D. O. B., Brown, A., Mestre, N. C., van Oevelen, D., Menot, L., Colaço, A., Canals, M., Cuvelier, D., Durden, J. M., Gebruk, A., Egho, G. A., Haeckel, M., Marcon, Y., Mevenkamp, L., Morato, T., Pham, C. K., Purser, A., Sanchez-Vidal, A., Vanreusel, A., Vink, A., and Martínez Arbizu, P.: Resilience of benthic deep-sea 
fauna to mining activities, Mar. Environ. Res., 129, 76-101, https://doi.org/10.1016/j.marenvres.2017.04.010, 2017.

Grassle, F. J. and Sanders, H. L.: Life histories and the role of disturbance, Deep-Sea Res., 20, 643-659, https://doi.org/10.1016/0011-7471(73)90032-6, 1973.

Haeckel, M., König, I., Riech, V., Weber, M. E., and Suess, E.: Pore water profiles and numerical modelling of biogeochemical processes in Peru Basin deep-sea sediments, Deep-Sea Res. Pt. II, 48, 3713-3736, https://doi.org/10.1016/S0967-0645(01)000649, 2001.

Hauton, C., Brown, A., Thatje, S., Mestre, N. C., Bebianno, M. J., Martins, I., Bettencourt, R., Canals, M., Sanchez-Vidal, A., Shillito, B., Ravaux, J., Zbinden, M., Duperron, S., Mevenkamp, L., Vanreusel, A., Gambi, C., Dell'Anno, A., Danovaro, R., Gunn, V., and Weaver, P.: Identifying toxic impacts of metals potentially released during deep-sea mining - A synthesis of the challenges to quantifying risk, Front. Mar. Sci., 4, 368, https://doi.org/10.3389/fmars.2017.00368, 2017.

Hein, J. R. and Koschinsky, A.: Deep-ocean ferromanganese crusts and nodules, in: The Treatise on Geochemistry, edited by: Scott, S., Elsevier, Amsterdam, the Netherlands, 13, 273-291, 2014.

Hein, J. R., Mizell, K., Koschinsky, A., and Conrad, T. A.: Deep-ocean mineral deposits as a source of critical metals for high- and green-technology applications: Comparison with land-based resources, Ore Geol. Rev., 51, 1-14, https://doi.org/10.1016/j.oregeorev.2012.12.001, 2013.

Howell, R.: Levels of heavy metal pollutants in two species of marine nematodes, Mar. Pollut. Bull., 13, 396-398, https://doi.org/10.1016/0025-326X(82)90117-5, 1982.

International Organization for Standardization: Soil quality - Dissolution for the determination of total element content - Part 2: Dissolution by alkaline fusion (ISO 14869-2:2002(E)), 2002.

Jain, S. K., Gupta, R., and Bindal, V. N.: Acoustic characteristics of polymetallic nodules collected from Central Indian Ocean Basin, Indian J. Mar. Sci., 28, 106-108, 1999.

Jones, D. O. B., Kaiser, S., Sweetman, A. K., Smith, C. R., Menot, L., Vink, A., Trueblood, D., Greinert, J., Billett, D. S. M., Martínez Arbizu, P., Radziejewska, T., Singh, R., Ingole, B., Stratmann, T., Simon-Lledó, E., Durden, J. M., and Clark, M. R.: Biological responses to disturbance from simulated deepsea polymetallic nodule mining, PLOS ONE, 12, e0171750, https://doi.org/10.1371/journal.pone.0171750, 2017.

Kaneko, T., Maejima, Y., and Teishima, H.: The abundance and vertical distribution of abyssal benthic fauna in the Japan Deep-Sea Impact Experiment, International Society of Offshore and Polar Engineers, Honululu, Hawaii, USA, 1997.

Koschinsky, A.: Heavy metal distributions in Peru Basin surface sediments in relation to historic, present and disturbed redox environments, Deep-Sea Res. Pt. II, 48, 3757-3777, https://doi.org/10.1016/S0967-0645(01)00066-2, 2001.

Leduc, D. and Pilditch, C. A.: Effect of a physical disturbance event on deep-sea nematode community structure and ecosystem function, J. Exp. Mar. Biol. Ecol., 440, 35-41, https://doi.org/10.1016/j.jembe.2012.11.015, 2013.

Lodge, M., Johnson, D., Le Gurun, G., Wengler, M., Weaver, P., and Gunn, V.: Seabed mining: International Seabed Authority environmental management plan for the ClarionClipperton Zone. A partnership approach, Mar. Policy, 49, 6672, https://doi.org/10.1016/j.marpol.2014.04.006, 2014.
Madureira, P., Brekke, H., Cherkashov, G., and Rovere, M.: Exploration of polymetallic nodules in the Area: Reporting practices, data management and transparency, Mar. Policy, 70, 101-107, https://doi.org/10.1016/j.marpol.2016.04.051, 2016.

Maurer, D., Keck, R. T., Tinsman, J. C., Leathem, W. A., Wethe, C., Lord, C., and Church, T. M.: Vertical migration and mortality of marine benthos in dredged material: A synthesis, Int. Rev. Ges. Hydrobio., 71, 49-63, https://doi.org/10.1002/iroh.19860710106, 1986.

McCann, K. S.: The diversity-stability debate, Nature, 405, 228233, 2000.

Mero, J. L.: Chapter 11 Economic aspects of nodule mining, Elsev. Oceanogr. Ser., 15, 327-355, https://doi.org/10.1016/S04229894(08)71025-0, 1977.

Mevenkamp, L., Stratmann, T., Guilini, K., Moodley, L., van Oevelen, D., Vanreusel, A., Westerlund, S., and Sweetman, A. K.: Impaired short-term functioning of a benthic community from a deep Norwegian fjord following deposition of mine tailings and sediments, Front. Mar. Sci., 4, 169, https://doi.org/10.3389/fmars.2017.00169, 2017.

Mevenkamp, L., Guilini, K., Boetius, A., De Grave, J., Laforce, B., Vandenberghe, D., Vincze, L., Vanreusel, A.: Experiment with crushed nodule substrate deposition for eleven days during SONNE cruise SO242/2, PANGAEA, https://doi.pangaea.de/10. 1594/PANGAEA.896027 (last access: 23 May 2019), 2018.

Miljutin, D. M., Miljutina, M. A., Martínez Arbizu, P., and Galéron, J.: Deep-sea nematode assemblage has not recovered 26 years after experimental mining of polymetallic nodules (Clarion-Clipperton Fracture Zone, Tropical Eastern Pacific), Deep-Sea Res. Pt. I, 58, 885-897, https://doi.org/10.1016/j.dsr.2011.06.003, 2011.

Murphy, K., Goulding, L., Munro, C., Ward, J., and Martin, A.: MIDAS Deliverable 7.3, Register of main impacts and causative factors, Environmental Resources Management Ltd., London, UK, 2016.

Oebius, H. U., Becker, H. J., Rolinski, S., and Jankowski, J. A.: Parametrization and evaluation of marine environmental impacts produced by deep-sea manganese nodule mining, DeepSea Res. Pt. II, 48, 3453-3467, https://doi.org/10.1016/S09670645(01)00052-2, 2001.

Pape, E., van Oevelen, D., Moodley, L., Soetaert, K., and Vanreusel, A.: Nematode feeding strategies and the fate of dissolved organic matter carbon in different deep-sea sedimentary environments, Deep-Sea Res. Pt. I, 80, 94-110, https://doi.org/10.1016/j.dsr.2013.05.018, 2013.

Paul, S. A. L., Gaye, B., Haeckel, M., Kasten, S., and Koschinsky, A.: Biogeochemical regeneration of a nodule mining disturbance site: Trace metals, DOC and amino acids in deepsea sediments and pore waters, Front. Mar. Sci., 5, 117, https://doi.org/10.3389/fmars.2018.00117, 2018.

Purser, A., Marcon, Y., Hoving, H.-J. T., Vecchione, M., Piatkowski, U., Eason, D., Bluhm, H., and Boetius, A.: Association of deep-sea incirrate octopods with manganese crusts and nodule fields in the Pacific Ocean, Curr. Biol., 26, R1268-R1269, https://doi.org/10.1016/j.cub.2016.10.052, 2016.

R Core Team: R: A language and environment for statistical computing., R Foundation for Statistical Computing, Vienna, Austria, available at: https://www.r-project.org/ (last access: 20 December 2018), 2013. 
Rex, M. A., Etter, R. J., Morris, J. S., Crouse, J., McClain, C. R., Johnson, N. A., Stuart, C. T., Deming, J. W., Thies, R., and Avery, R.: Global bathymetric patterns of standing stock and body size in the deep-sea benthos, Mar. Ecol. Prog. Ser., 317, 1-8, https://doi.org/10.3354/meps317001, 2006.

Rolinski, S., Segschneider, J., and Sündermann, J.: Long-term propagation of tailings from deep-sea mining under variable conditions by means of numerical simulations, Deep-Sea Res. Pt. II, 48, 3469-3485, https://doi.org/10.1016/S0967-0645(01)000534, 2001.

Rosli, N., Leduc, D., Rowden, A. A., Probert, P. K., and Clark, M. R.: Regional and sediment depth differences in nematode community structure greater than between habitats on the New Zealand margin: Implications for vulnerability to anthropogenic disturbance, Prog. Oceanogr., 160, 26-52, https://doi.org/10.1016/j.pocean.2017.11.006, 2018.

Rzeznik-Orignac, J., Fichet, D., and Boucher, G.: Extracting massive numbers of nematodes from muddy marine deposits: efficiency and selectivity, Nematology, 6, 605-616, https://doi.org/10.1163/1568541042665287, 2004.

Schratzberger, M. and Ingels, J.: Meiofauna matters: The roles of meiofauna in benthic ecosystems, J. Exp. Mar. Biol. Ecol., 502, 12-25, https://doi.org/10.1016/j.jembe.2017.01.007, 2017.

Schratzberger, M., Rees, H. L., and Boyd, S. E.: Effects of simulated deposition of dredged material on structure of nematode assemblages - the role of burial, Mar. Biol., 136, 519-530, https://doi.org/10.1007/s002270050712, 2000.

Sharma, R., Nagender Nath, B., Parthiban, G., and Jai Sankar, S.: Sediment redistribution during simulated benthic disturbance and its implications on deep seabed mining, Deep-Sea Res. Pt. II, 48, 3363-3380, https://doi.org/10.1016/S0967-0645(01)000467, 2001.

Singh, R., Miljutin, D. M., Miljutina, M. A., Martinez Arbizu, P., and Ingole, B. S.: Deep-sea nematode assemblages from a commercially important polymetallic nodule area in the Central Indian Ocean Basin, Mar. Biol. Res., 10, 906-916, 2014.

Sinniger, F., Pawlowski, J., Harii, S., Gooday, A. J., Yamamoto, H., Chevaldonné, P., Cedhagen, T., Carvalho, G., and Creer, S.: Worldwide analysis of sedimentary DNA reveals major gaps in taxonomic knowledge of deep-sea benthos, Front. Mar. Sci., 3, 92, https://doi.org/10.3389/fmars.2016.00092, 2016.

Smith, C. R., Levin, L. A., Koslow, A., Tyler, P. A., and Glover, A. G.: The near future of the deep-sea floor ecosystems, in: Aquatic Ecosystems, edited by: Polunin, N., Cambridge University Press, Cambridge, 334-351, 2008.

Somerfield, P. J., Warwick, R. M., and Moens, T.: Meiofauna techniques, in: Methods for the study of marine benthos, edited by: Eleftheriou, A. and McIntyre, A., 3rd edn., Blackwell Science, Oxford, UK, 229-272, 2005.

Stummeyer, J. and Marchig, V.: Mobility of metals over the redox boundary in Peru Basin sediments, Deep-Sea Res. Pt. II, 48, 3549-3567, https://doi.org/10.1016/S0967-0645(01)00056$\mathrm{X}, 2001$.
Thiel, H.: Evaluation of the environmental consequences of polymetallic nodule mining based on the results of the TUSCH Research Association, Deep-Sea Res. Pt. II, 48, 3433-3452, https://doi.org/10.1016/S0967-0645(01)00051-0, 2001.

Thiel, H. and Schriever, G.: Cruise report DISCOL 1, SONNEcruise 61, Ber. Zentrum Meeres-u. Klimaforsch. Univ. Hamburg, Hamburg, Germany 3, 1-75, 1989.

Thiel, H., Schriever, G., Bussau, C., and Borowski, C.: Manganese nodule crevice fauna, Deep-Sea Res. Pt. I, 40, 419-423, https://doi.org/10.1016/0967-0637(93)90012-R, 1993.

Uhlig, G., Thiel, H., and Gray, J. S.: The quantitative separation of meiofauna, Helgoland. Wiss. Meer., 25, 173 pp. https://doi.org/10.1007/BF01609968, 1973.

Vanreusel, A., Van den Bossche, I., and Thiermann, F.: Freeliving marine nematodes from hydrothermal sediments: similarities with communities from diverse reduced habitats, Mar. Ecol. Prog. Ser., 157, 207-219, 1997.

Vanreusel, A., Fonseca, G., Danovaro, R., Da Silva, M. C., Esteves, A. M., Ferrero, T., Gad, G., Galtsova, V., Gambi, C., Da Fonsêca Genevois, V., Ingels, J., Ingole, B., Lampadariou, N., Merckx, B., Miljutin, D., Miljutina, M., Muthumbi, A., Netto, S., Portnova, D., Radziejewska, T., Raes, M., Tchesunov, A., Vanaverbeke, J., Van Gaever, S., Venekey, V., Bezerra, T. N., Flint, H., Copley, J., Pape, E., Zeppilli, D., Martinez Arbizu, P., and Galeron, J.: The contribution of deep-sea macrohabitat heterogeneity to global nematode diversity, Mar. Ecol., 31, 6-20, https://doi.org/10.1111/j.1439-0485.2009.00352.x, 2010.

Vanreusel, A., Hilario, A., Ribeiro, P. A., Menot, L., and Martínez Arbizu, P.: Threatened by mining, polymetallic nodules are required to preserve abyssal epifauna, Sci.-Rep. UK, 6, 26808, https://doi.org/10.1038/srep26808, 2016.

Volz, J. B., Mogollón, J. M., Geibert, W., Martinez Arbizu, P., Koschinsky, A., and Kasten, S.: Natural spatial variability of depositional conditions, biogeochemical processes and element fluxes in sediments of the eastern Clarion-Clipperton Zone, Pacific Ocean, Deep-Sea Res. Pt. I, 140, 159-172, https://doi.org/10.1016/j.dsr.2018.08.006, 2018.

Von Stackelberg, U.: Manganese nodules of the Peru Basin, in: Handbook of Marine Mineral Deposits, edited by: Cronan, D S., CRC Press, Boca Raton, Florida, USA, 197-238, 2000.

Wentworth, C. K.: A Scale of grade and class terms for clastic sediments, J. Geol., 30, 377-392, 1922.

Wieser, W.: Die Beziehungen zwischen Mundhöhlengestalt, Ernährungsweise und Vorkommen bei freilebenden marinen $\mathrm{Ne}$ matoden, Arkiv Zool., 4, 439-484, 1953.

Zenhorst, J.: Degradation of poly-metallic nodules in a dredge pump, Masters thesis, Delft University of Technology, Delft, the Netherlands, 2016. 